\title{
PROBLEMA MORTTII ÎN GÂNDIREA PĂRINTELUI STĂNILOAE
}

Florin GAȘPAR*

\begin{abstract}
The Problem of Death in Father Stăniloae's Thinking ${ }^{1}$. The purpose to this study is to highlight Father's Stăniloae theological reflections on the issue of death. In order to do that, the main objectives are: to show, firstly, that Father Stăniloae's doctrine on death was inspired by the writings of Saints Maxim the Confessor, John Damascene, Simeon Metaphrastes, John Chrysostom, and Gregory of Nyssa; the second objective is to present how Father Stăniloae divides the existence of the creation into three stages: the creation before Christ, in Christ, and the one after the end of the present form of the world. The man and the cosmos continuously tend towards eschaton. Death is a gateway to life and it represents the transition from temporal to eternal. Christian's true life begins only after his death. Death is therefore the way to full union with Christ, and it is the door through which we will step beyond mirror and guesses. The fear of death is due to the consciousness of the sinful state that separated the man from God; this fear comes out of thinking at the eternal torment. By uniting himself with Christ, the believer gradually overcomes this fear - that's why the saints welcome their death joyfully. Death is a mystery of God for us. Father Stăniloae presents death as the result of two consequences: of human freedom - namely death as the weakening of the soul in the flesh - and death as the teaching of life before God.
\end{abstract}

Keywords: body, death, Dumitru Stăniloae, eternal life, eschatology, soul.

* Priest, PhD Student, Faculty of Orthodox Teology „Ilarion V. Felea” at „Aurel Vlaciu” University, Arad, Romania.

${ }^{1}$ Lucrare publicată sub îndrumarea Pr. Prof. Dr. Cristinel Ioja, care și-a exprimat acordul pentru publicare. 


\section{Introducere}

În cele ce urmează îmi propun să prezint învățătura ortodoxă privitoare la moarte, aşa cum reiese aceasta din scrierile părintelui Dumitru Stăniloae.

Moartea este calea către unirea deplină cu Hristos, este uşa prin care vom păși dincolo de oglindă, de ghicitură. „Moartea este prăpastia sau puntea universală de trecere spre o altă existență, spre existența veșnică" ${ }^{2}$. Tocmai de aceea moartea umple de sens existența omului, care știe că viața lui nu se va încheia cu experiența pământească de scurtă durată, ci că, după această trecere, el va continua să trăiască veșnic.

Moartea a adus ceva nefiresc în fire ${ }^{3}$. Tocmai de aceea conștiința omului nu poate accepta moartea ca ultimă realitate a existenței sale.

Creștinismul a transformat moartea din moment înspăimântător în trecere spre o viață veșnică cu Hristos cel înviat. În acest sens, creștinul se pregătește în cursul vieții pământești ,prin întărirea în comuniunea cu Hristos, pentru ca moartea sa să fie trecerea lui la plenitudinea comuniunii cu Dumnezeu și cu semenii" lui Dumnezeu. Omul refuză comuniunea cu Dumnezeu și își îndreaptă atenția spre o comuniune idolatră cu sine și creația, exploatând ceea ce Dumnezeu i-a dat pentru mântuire, pentru noi surse de plăceri care să poată înlocui pe Creator cu cele create. Păcatul înseamnă pierderea vieții și identităţii absolute conferite de Dumnezeu în spațiul iubirii. Părintele Stăniloae spune că:

„Liniștirea dată de către satana primilor oameni, că prin întoarcerea de la Dumnezeu spre plăcerile materiale și trecătoare ale naturii nu vor muri, a pus stăpânire pe gândirea lor în cursul istoriei, în măsură tot mai mare. Moartea nu le mai apărea în toată grozăvia ei, pentru că și valoarea omului se estompase, socotindu-l ca produs al unor legi ale naturii”'

De aici pornește conceptul de moarte ca slăbire a sufletului în trup.

2 Dumitru Stăniloae, Teologia dogmatică ortodoxă, vol. III, București, Edit. Institutului Biblic şi de Misiune Ortodoxă, 2010, p. 224.

3 Dumitru Stăniloae, Chipul nemuritor al lui Dumnezeu, Craiova, Edit. Mitropoliei Olteniei, 1987, p. 68.

${ }^{4}$ Dumitru StăniloAe, Teologia dogmatică ortodoxă, vol. III, p. 230.

${ }^{5}$ Dumitru StăniloAe, Chipul nemuritor al lui Dumnezeu, p. 187. 


\section{Moartea ca predare a vieții înaintea lui Dumnezeu}

Cine se împacă într-un mod delăsător cu gândul că va muri nu se mai neliniștește de nimic. El rămâne indiferent față de moarte, nu din cauza unei credințe ferme în viața viitoare, ci din cauza unei surde cunoașteri a adevăratului sens al vieții: îndumnezeirea ${ }^{6}$.

Pentru că nimeni nu știe ceasul morții sale, trebuie să fie stăpân pe sine însuși în fața morții, pregătit în orice clipă să moară. De aceea creștinii se luptă cu pornirile pătimașe ale trupului, căutând viața în comuniune cu Dumnezeu:

„Omul se pregătește în cursul întregii vieți pământești prin întărirea în comuniunea cu Hristos, pentru ca moartea sa să fie trecerea lui la plenitudinea comuniunii cu Dumnezeu și cu semenii'”’

Cel ce are pomenirea neîncetată a morții nu poate afirma niciodată că e pregătit pentru ea sau că a ajuns la desăvârșire și la deplinătatea curăției. Cel ce ar afirma aceasta, cu siguranță că nu ar fi demn de crezare pentru că îi lipsește smerenia. Or, tocmai gândind la moarte, te smerești și consideri timpul care ția mai rămas pe acest pământ drept cale de înaintare nesfârșită spre cer .

În această pregătire, foarte folositor este gândul la moarte sau continua pomenire a morții. Sf. Antonie cel Mare surprinde folosul acestei filosofii:

„Moartea de o va avea omul în minte, nemurire este; iar neavând-o în minte, moarte este. Dar nu de moarte trebuie să ne temem, ci de pierderea sufletului, care este necunoștința lui Dumnezeu" ".

Pe lângă acest gând, este recomandat gândul la judecată, la chinurile iadului, la pedeapsa sau răsplata veșnică. În acest sens, Evagrie Monahul recomandă pentru ferirea de patimi gândul la chinurile iadului: „Mută-ți gândul și la starea cea din iad, gândește-te cum se chinuiesc sufletele acolo, în ce tăcere prea amară" ${ }^{\prime 10}$.

${ }^{6}$ Filocalia, vol. VIII, trad. Dumitru StĂNILOAe, București, EIBMBOR, 1979, nota 63, p. 52.

${ }^{7}$ Dumitru StăniloAe, Teologia dogmatică ortodoxă, vol. III, p. 230.

8 Scara Sfântului IoAn ScĂrarul, în Filocalia, vol. IX, trad. Dumitru Stăniloae, București, EIBMBOR, 1980, nota 305, p. 161.

${ }^{9}$ SFÂNTUl ANTONIE CEl MARE, Invățături despre viața monahală, în Filocalia, vol. I, Ed. a II-a, trad. Dumitru STĂNILOAE, Sibiu, 1947, p. 12.

${ }^{10}$ Filocalia, vol. I, p. 45-46. 
Creștinul care îşi caută mântuirea luptă cu gândul vieții și-i spune acestuia: „Am murit și zac în mormânt”, nu în ideea unei disprețuiri a vieții pământești, ci în ideea responsabilizării sufletului în lupta cu trupul ce poftește împotriva lui și cu legăturile ce îl țin legat pe acesta într-o viață moartă și fără sens. E vorba și de moartea egoismului pentru a trăi în Dumnezeu și pentru semeni ${ }^{11}$.

Umplerea de Dumnezeu e direct proporțională cu renunţarea la sine. „, $\mathrm{Cu}$ cât moare cineva mai mult sieși, cu atât se umple mai mult de iubirea lui Dumnezeu, care e infinită, fiind a Subiectului infinit"12. Păcatul aduce alterarea firii, moartea sufletului, încă din timpul vieții trupului. Cel ce-și dorește adevărata viață, trebuie să o caute pe cea nemuritoare ce izvorăște din Dumnezeu:

„Luptă-te să mori după omul cel vechi, să mori vieţii «moarte», ca să intri în viaţa adevărată nemuritoare, pe care o câștigăm din Dumnezeu, izvorul vieţii cînd ne unim cu el"13.

Din această perspectivă moartea capătă o nouă dimensiune: moartea față de păcat și predarea în mâinile lui Dumnezeu, o moarte a simţirii ce îl scoate pe om din moartea firii:

„Moartea simţirii e menită să mântuiască pe om de moartea firii. Moartea ca osândă a fost pricinuită de creşterea lucrării simţurilor, care 1-a legat pe om de lumea văzută, despărţindu-1 de Dumnezeu. Moartea simţirii e moartea omului trupesc, a omului aplecat spre cele de dinafară, a omului «mort» duhovniceşte, pentru a învia omul dinăuntru, omul adevărat, omul mintal, sinea omului"”14.

Astfel, murind și biruind păcatul și predându-se lui Dumnezeu dea lungul întregii vieți, despărțirea sufletului de trup înseamnă acum ultima predare totală lui Dumnezeu:

11 „Luptă-te să mori morții, să mori față de ce te face mort, adică față de tot ce te robește; luptăte să te deschizi vieții generoase, să te ridici în lărgimea liberă a adevăratei vieți” (SFINȚII VARSANUFIE și IOAN, Scrisori duhovnicești, în Filocalia, vol. XI, trad. Dumitru STĂNILOAE, Edit. Apologeticum, 2005, Ediție electronică, nota 87, p. 88; vezi și nota 104b, p. 105).

12 Scara ..., în Filocalia, vol. IX, nota 939, p. 421.

${ }^{13}$ Sfinți VARSANUfie și IOAN, Scrisori..., în Filocalia, vol. XI, nota 225, p. 211; vezi și notele 246, 245.

${ }^{14}$ SFÂNTUL MAXIM MĂRTURISITORUL, Răspunsuri către Talasie, în Filocalia, vol. III, trad. Dumitru STĂNILOAE, Edit. Apologeticum, 2005, Ediție electronică, nota 549, p. 389. 
„Înțeleasă ca predare lui Dumnezeu, realizată mai mult sau mai puțin deplin în momentul final, dar mereu prezentă ca intenție și ca mișcare în viaţă, moartea se poate socoti predare completă a omului lui Dumnezeu în momentul morții, chiar în creștinul luat de moarte pe neașteptate, căci toată viața lui trăită ca o predare tot mai deplină lui Dumnezeu include în ea intenția predării totale" $" 15$.

Hristos e mereu disponibil să primească cu iertare pocăința omului, fie aceasta și în ultimele clipe ale vieții. Ca exemplu al acestei predări totale în ceasul morții, părintele Stăniloae îl dă pe tâlharul de pe cruce, care prin moartea sa alături de Hristos și cu credința în puterea Lui, el a câștigat raiul. O mare ruşine îi va cuprinde pe cei ce în ceasul morții nu s-au îngrijit de nici un lucru care le-ar putea face vreun bine.

Vorbim deci de o dublă moarte, cauzată de patimi și de omorârea morții prin răstignirea patimilor din dragoste de Dumnezeu. Există o pătimire dureroasă sau dulce pătimire și o pătimire plăcută sau o pasiune de plăcere. A-ți lua crucea și a urma lui Hristos, lepâdându-te pe tine însuți, lumea și ,calea cea largă”, este o rea pătimire. Dulcea pătimire este legătura pătimașă de lume, prin plăcerile lumești, ce oferă satisfacții trecătoare trupului muritor ${ }^{16}$. Părintele Stăniloae explică ce înseamnă patimă de plăcere și patimă de durere ${ }^{17}$.

Lumea este prin natura ei destinată să fie jertfită lui Dumnezeu şi de aceea mântuirea lui Hristos are forma morţii ca jertfă; dar destinaţia aceasta s-a dat lumii în vederea tainei lui Hristos. Sau, pe un plan mai înalt, voluntar şi duhovnicesc, Hristos împlineşte o lege, pe care, involuntar şi natural, trebuie să o împlinească toată zidirea. E o lege supremă, după care tot ce e muritor trebuie să moară pentru a primi nemurirea, neputând coexista elementul muritor cu cel nemuritor în aceeaşifiinţă, sau creatul cu funcţie activă cu necreatul primit ca har. Sau altfel:

„Făptura ori se mistuie duhovniceşte ca omagiu adus lui Dumnezeu, dacă vrea să trăiască prin El, sau e omorâtă de păcat şi pedeapsă. Ea trebuie să aleagă o moarte, sau moartea spre viaţă, sau moartea spre moarte"18.

15 Dumitru StăniloAe, Teologia dogmatică ortodoxă, vol. III, p. 236.

${ }^{16}$ Filocalia, vol. VIII, nota 144, p. 79.

17 Vezi: Filocalia, vol. VII, trad. Dumitru STĂniloAe, București, EIBMBOR, 1977, nota 222, p. 157.

18 Sfântul Maxim Mărturisitorul, Cuvânt ascetic, Capete despre dragoste, Capete 
De aceea, comentând textul lui Isai Pustnicul, părintele Stăniloae afirmă că nemurirea constă și în despătimire, în păzirea simțurilor, în ferirea de păcate și în iluminarea Sf. Duh ${ }^{19}$. În acelaţi sens, Ioan Scărarul afirmă:

„Cel ce iubește cu adevărat pe Domnul, cel ce se străduiește cu adevărat să ajungă la viața viitoare, cel ce are cu adevărat durere pentru greșelile lui, cel ce a dobândit cu adevărat aducerea aminte de osânda și de judecata veșnică, cel ce a primit cu adevărat frica de moartea sa, nu va mai iubi, nu se va mai îngriji nici de bani, nici de averi, nici de părinți, nici de slava vieții, nici de prieteni, nici de frați, peste tot, de nimic pământesc, ci lepădând și urând toată legătura, toată grija de acestea, ba încă înainte de acestea și trupul său, urmează gol și fără griji și fără pregetare, lui Hristos, privind pururea spre cer şi așteptând ajutorul de acolo"20.

Predarea totală lui Dumnezeu e însoțită și de ascultare, spune părintele Stăniloae, iar Sf. Ioan Scărarul o numește pe aceasta mormânt al voii proprii și înviere a smereniei ${ }^{21}$. În această ascultare nu există frică, ci cel ce ascultă de Dumnezeu împlinește poruncile Lui din iubire:

„Din iubirea de Dumnezeu acceptă omul toată asceza sa, care sfârșește în moarte. Din iubirea de Dumnezeu-Tatăl, dar și de om, a primit Fiul lui Dumnezeu moartea ca om, pentru ca noi să putem muri cu El la fel din iubire față de Dumnezeu"22.

În Hristos dăruirea față de om până la moartea pe cruce atinge cote maxime. De aceea, noi avem opțiunea de a muri sufletește, refuzând comuniunea iubitoare cu Hristos și semeni și trăind în mod egoist și pătimaș cu ceea ce Dumnezeu ne-a dat pentru a întreține și bucura viața noastră, ori putem fi după modelul lui Hristos făcători de pace ai lumii, prieteni iubitori și apropiaţi ai tuturor și, mai presus decât toate, rugători ascultători și credincioși ai lui Iisus. Aceasta este moarte din generozitate. Iar această moarte

teologice, Întrebări, nedumeriri şi răspunsuri, Tâlcuire la Tatăl nostru, în Filocalia, vol. II, trad. Dumitru STĂNILOAE, Edit. Apologeticum, 2005, Ediție electronică, nota 347, p. 193-194.

${ }^{19}$ Cuviosul Isaia Pustnicul, Douăzeci și nouă de cuvinte, în Filocalia, vol. XII, trad.

Dumitru STĂNILOAE, București, Edit. Harisma, 1991, nota 89, p. 65.

${ }^{20}$ Scara ..., în Filocalia, vol. IX, p. 60-61.

${ }^{21}$ Ibidem, p. 79.

${ }^{22}$ Dumitru StănilOAe, Teologia dogmatică ortodoxă, vol. III, p. 243. 
„înseamnă ieşirea din închisoarea egoismului. Moartea de pe urma păcatului înseamnă a te sărăci şi sufoca în strâmtoarea egoismului tău. Noi purtăm în noi moartea din egoism chiar din sămânţa părinţilor din care ne naştem. Dar o putem preface în moarte din generozitate. Şi aceasta ne trece la viaţă. Ne naştem în orice caz ca să murim: să murim de moartea de bunăvoie a iubirii faţă de alţii, sau de moartea din egoism"23.

În procesul despătimirii, creștinul este ajutat prin Sfintele Taine, în care prin comuniunea cu Hristos ce se oferă în grade și moduri diferite tainic creștinului în Biserică, acesta poate să moară sieși pentru a se preda lui Dumnezeu ${ }^{24}$.

\section{Moartea ca slăbire a sufletului în trup}

Dacă mai sus am prezentat moartea ca predarea a omului lui Dumnezeu, prin izbăvirea din robia patimilor, la polul opus, se întâlnește la părintele Stăniloae ideea că moartea este slăbirea sufletului în trup, slăbire cauzată de ruperea comuniunii cu Dumnezeu, prin păcate.

Creștinul, prin credință, așteaptă cu nădejde moartea ca poartă spre viață. El crede, dar niciodată nu cunoaște deplin felul vieții de după moarte:

„Noi știm formal că ajungem acolo, dar cum este acel «acolo» nu știm, afară de oarecare licărire a lui prin vălul vieții noastre în trup, care începe să se sfâșie, sau a devenit din ce în ce mai diafan pentru sfinți și pentru creștinii îmbunătățiți”’25.

Părăsind pe Dumnezeu izvorul vieții, omul se închide în spaţiul morții, moartea apare ca o consecință a ruperii comuniunii cu Dumnezeu și orientării spre creație, ca având sursa vieții în sine și nu în Dumnezeu. Iar această despărțire de Dumnezeu e fapta omului. De aceea, nu

${ }^{23}$ Sfinți VARSANUfie Și IoAn, Scrisori..., în Filocalia, vol. XI, nota 308, p. 282.

24 Părintele Stăniloae are mai multe tratate despre Sfintele Taine ale Bisericii: „Ființa tainelor în cele trei confesiuni”, în Ortodoxia, nr. 1/1956; „Numărul Tainelor, raporturile dintre ele și problema Tainelor în afara Bisericii”, în Ortodoxia, nr. 8/1956, nr. 2, p. 191-215; „Din aspectul sacramental al Bisericii”, în Studii Teologice, nr. 910/1966; „Creația ca dar și Tainele Bisericii”, în: Ortodoxia, nr. 1/1976; Spiritualitate şi comuniune în Liturghia ortodoxă, Craiova, Edit. Mitropoliei Olteniei, 1987.

${ }^{25}$ Dumitru Stăniloae, Teologia dogmatică ortodoxă, vol. III, p. 239. 
Dumnezeu a făcut moartea ${ }^{26}$. Părintele Stăniloae arată că prin ruperea comuniunii cu Dumnezeu e afectat întâi sufletul omului, iar mai apoi, prin suflet, şi trupul:

„Oamenii ieșind din legătura cu Cuvântul ipostatic și în general cu Dumnezeu cel în Treime ca izvor al vieții, au murit. Au murit sufletește, dar aceasta le-a adus și moartea trupului"’27.

Dar niciodată omul nu e pierdut. Prin pocăință, el poate reveni din nou la cele dintâi, adică la afirmarea spiritului față de trup. Iată ce spune Sf. Ioan Scărarul: „Ascultarea stă în a-și tăgădui cineva cu desăvârșire sufletul său, fapt arătat în chip vădit prin trup". Aceasta nu înseamnă o negare a sufletului, ci predarea lui, lui Dumnezeu. Prin ascultare, care e mormânt al voii proprii și înviere a smereniei, omul poate dobândi din nou supremația sufletului în mişcarea trupului său și a-l salva pe acesta de la chinurile veșnice ${ }^{28}$.

Moartea, în general, e înțeleasă ca îmbătrânirea materiei trupului până la încetarea funcțiilor sale vitale. De aceea se și vorbește de materie tânără și materie bătrână sau trup tânăr și trup bătrân. Părintele Stăniloae afirmă că nu materia în sine e tânără și bătrână și nu materia merge spre moarte, ci sufletul, slăbindu-și funcțiile în trupul omului. Sufletul slăbește în trup prin ruperea de Dumnezeu, izvorul vieții:

„Sufletul și-a slăbit, prin ieșirea din comuniunea cu Dumnezeu, funcțiile de închegare și susținere a materiei în trup. Iar oprirea totală a activităţii acestor funcții este una cu moartea trupului’"29.

Astfel, moartea intră în creație ca un proces lent, dar sigur, cauzat de îndreptarea pătimașă a omului înspre sine și lumea văzută ca realităti ce îi aduc fericirea, viața și veșnicia:

„Despărțirea omului de Dumnezeu, Izvorul vieții spirituale, a slăbit, pe de o parte, forța de iradiere a spiritului omenesc prin trup, pe de alta, a făcut trupul în mare parte opac și fața hidoasă, nesimpatică, prin faptul că omul s-a ocupat în cea mai mare măsură, dacă nu exclusiv, de

${ }^{26}$ SfÂntul IsaAc SiRul, Cuvinte despre sfintele nevoințe, în Filocalia, vol. X, trad.

Dumitru STĂNILOAE, București, EIBMBOR, 1981, nota 273, p. 249.

${ }^{27}$ Dumitru StăniloAe, Chipul nemuritor al lui Dumnezeu, p. 22.

${ }^{28}$ Scara ..., în Filocalia, vol. IX, nota 129, p. 78.

${ }^{29}$ Ibidem, p. 84. 
plăcerile sale egoiste. Mișcările pătimașe din el au fost şi cauza descompunerii treptate a trupului, descompunere terminată prin moarte. Omul aproape că și-a pierdut conștiința că are un spirit stăpân pe mișcările pătimașe și însetat după îmbogățirea din Absolutul personal. Spiritul și-a pierdut puterea asupra trupului, care agitat de lăcomie, de voluptăți și de eforturile consumului, capătă o față urâtă, nesinceră și se descompune treptat" 30 .

Legat de această urâțire și stricăciune a trupului, Sf. Grigorie Palama vorbește de cei ce, prin viaţa lor în comuniunea cu diavolul, au luat în trupurile lor însuşirile aceluia pe care 1-au slujit, lepădând chipul luminos după care au fost creați:

„Din sufletul descurajat, pizmaş, scârbit, plin de ură, trece și în trup o stare de tristețe, de apăsare, de slăbiciune, de moleșeală nevindecabilă, toate aducătoare de moarte și întreținând moartea"31.

Părintele Stăniloae remarcă cât de importantă este comuniunea dintre oameni după chipul comuniunii Treimice. Ruperea comuniunii cu Dumnezeu aduce după sine şi ruperea comuniunii dintre oameni:

„Viaţa este astfel, o întărire a firii umane în unitatea ei și în legătura cu Dumnezeu. Iar moartea o slăbire a unităţii firii umane în ea însăşi și în legătura cu Dumnezeu. Oamenii și-au procurat astfel, prin păcat, nu numai despărțirea de Dumnezeu, ci și despărțirea între ei. Slăbind firea în unul și slăbind prin aceasta și legătura cu Dumnezeu în el, a slăbit-o și în ceilalţi. De aceea, cu cât e mai slăbită unitatea între persoane, cu atât își provoacă ei înșişi mai mult moartea unii altora și ajung până a se bucura reciproc de moartea lor" 32 .

Iată cum moartea ca slăbire a spiritului în trup este legată nu numai de unele despărțiri individuale ale omului de Dumnezeu, ci ale oamenilor în general, ca rupturi între ei, creație și Dumnezeu, ca închideri egoiste în sine, care pornesc din despărțirea de Dumnezeu și se răsfrâng asupra întregii creații. Lumea și omul în general despărțindu-se de Dumnezeu devin muritori ${ }^{33}$.

${ }^{30}$ Ibidem, p. 196.

${ }^{31}$ Filocalia, vol. VII, nota 715, p. 457.

32 Dumitru Stăniloae, Chipul nemuritor al lui Dumnezeu, p. 69.

${ }^{33}$ Cuviosul Isaia Pustnicul, Douăzeci şi nouă ..., în Filocalia, vol. XII, nota 331, p. 163. 
Schimbarea se produce prin învierea lui Hristos. Setea de eternitate a omului se împlinește în învierea lui Hristos, prin care spiritul este din nou tare în trupul îndumnezeit al Domnului ${ }^{34}$.

Apare întrebarea: Ce se întâmplă cu cei ce murind și înviind cu Hristos în Sfânta Taină a Botezului mai suferă de coruptibilitate și moarte?

1. Spiritul slăbind din ce în ce mai mult în trup, nu mai are capacitatea de a reveni la afirmarea sa asupra trupului. Păcatul a produs răni adânci în sufletul omenesc. Omul, deși vede binele, este mult mai aplecat către săvârșirea răului.

2. Materia devine din ce în ce mai greu de pătruns prin spirit, nu mai poate fi biruită de spirit și dusă de acesta prin înviere la transparența absolută.

3. Moartea și coruptibilitatea devin legi generale ale trupurilor. Omul botezat primește în Sfầnta Taină a Botezului armele luptei, întărirea și scutul de apărare. El este lăsat ca prin merite proprii și năzuințe să crească spiritual până la momentul învierii, care va însemna unirea trupului înduhovnicit cu sufletul spre o viață veșnică fericită. Această creștere spirituală pe care omul o primește ca potență sigură a vieții sale, întărit fiind încă de la Botez, se realizează prin moartea față de trupul pătimaș, pofte și plăceri egoiste și trecătoare și îndreptarea spre Dumnezeu și semeni ca persoane demne de iubit. Iubind pe Dumnezeu și întreaga creație în Dumnezeu, omul își găsește adevăratul sens și i se descoperă adevărata viață: viața în comuniune cu Dumnezeu și semenii săi. Din această viață trupul va trăi veșnic.

\section{Concluzii}

Se poate spune că în general sunt două feluri de morți: moartea ca slăbire a sufletului în trup, trăită ca un fapt pur negativ de pe urma pornirilor spre rău și a orgoliului care desparte de Dumnezeu și moartea ca predare lui Dumnezeu, venită de pe urma exercitării în moartea față de pornirile spre rău și față de o viață străină de Dumnezeu ${ }^{35}$.

Cel mai de preț lucru pe care omul îl poate pierde este sufletul său (Mt. 16, 26). Sf. Simeon Noul Teolog vorbește despre trupul mort prin

\footnotetext{
${ }^{34}$ Dumitru STăNILOAe, Chipul nemuritor al lui Dumnezeu, p. 53-54.

${ }^{35}$ Dumitru StĂniloAe, Teologia dogmatică ortodoxă, vol. III, p. 241.
} 
patimi în care sufletul este aproape imposibil de mișcat spre orice poruncă a lui Dumnezeu. Părintele Stăniloae în legătură cu aceasta afirmă că ,,întrun trup viu pentru patimi, sufletul e mort" 36 .

Sfinții Părinți recomandă pentru o predare a vieții lui Dumnezeu gândul la judecată, la chinurile iadului, la pedeapsa sau răsplata veșnică, purtarea cu credință și necârtire a pătimirilor celor dureroase, murind pentru lume, pentru a trăi în Dumnezeu. În acest sens, Biserica îi oferă omului un ajutor - Sfintele Taine, care sunt pentru creștin adevărată întărire în lupta cu patimile, cu scopul apropierii de Dumnezeu.

\section{Referinţe bibliografice:}

1. StăniloAe, Dumitru, Filocalia, vol. I, Ed. a II-a, Sibiu, 1947;

2. Stăniloae, Dumitru, Filocalia, vol. II, Apologeticum, 2005, Ediție electronică;

3. StăniloAe, Dumitru, Filocalia, vol. III, Apologeticum, 2005, Ediție electronică;

4. StăNILOAE, Dumitru, Filocalia, vol. IV, Sibiu, 1948;

5. STĂNILOAE, Dumitru, Filocalia, vol. IX, EIBMBOR, București, 1980;

6. STĂNILOAE, Dumitru, Filocalia, vol. VI, EIBMBOR, București, 1977;

7. STĂNILOAE, Dumitru, Filocalia, vol. VII, EIBMBOR, București, 1977;

8. STĂNILOAE, Dumitru, Filocalia, vol. VIII, EIBMBOR, București, 1979;

9. STĂNILOAE, Dumitru, Filocalia, vol. X, EIBMBOR, București, 1980;

10. StănILOAE, Dumitru, Filocalia, vol. X, Harisma, București, 1991;

11. StăniloAe, Dumitru, Filocalia, vol. XI, Apologeticum, 2005, Ediţie electronică;

12. StĂniloAe, Dumitru, Chipul nemuritor al lui Dumnezeu, Craiova, Edit. Mitropoliei Olteniei, 1987;

13. STĂNILOAE, Dumitru, Spiritualitate și comuniune în Liturghia ortodoxă, Craiova, Edit. Mitropoliei Olteniei, 1987;

14. StăniloAe, Dumitru, Teologia dogmatică ortodoxă, vol. III, București, EIBMBOR, 2010.

36 Sfântul Simeon Noul Teolog, Filocalia, vol. VI, trad. Dumitru Stănilone, București, EIBMBOR, 1977, nota 36, p. 29. 